\title{
Formalities and Regulations Governing the Arbitration Proceedings in International Law
}

\author{
Mohsen Hosein Abadi $^{1}$ \& Alireza Azadi Kalkoshki ${ }^{1}$ \\ ${ }^{1}$ FEBIT International Law Office \\ Correspondence: Alireza Azadi Kalkoshki, FEBIT International Law Office. E-mail: f.o.20@febitmail.com
}

Received: May 10, 2017

Accepted: June 10, $2017 \quad$ Online Published: August 30, 2017

doi:10.5539/jpl.v10n4p108

URL: https://doi.org/10.5539/jpl.v10n4p108

\begin{abstract}
The traditionally emergence of differences among people, common and perhaps it was natural and it is not usually considered in relations between individuals does not seem far-fetched idea origination dispute. With the growing human population and the natural growth of business and trade transactions between them and the complexity of certain fields of these transactions disputes arising from them, more and more widespread and sometimes even has been specialized. It went to the point in one of the last two centuries, several laws passed by the government to resolve the current dispute and with forming the courts for a variety of dispute resolution between individuals, many branches of the courts dedicated to legal and commercial affairs and handle their disputes. All countries dispute arises between individuals were appointed to the courts; although this is associated with the severity and weaknesses in different countries and legal systems. Some with creates parallel institutions for the courts try to reduce congestion in the courts claims and others by creating a concentration of executive power in the courts were concerned their main effort in resolving disputes before the court. Except for the courts in recent centuries in most societies with little differences in the shape and nature of the investigation into the allegations were established, in the last century, another institution for dispute between individuals was created in many countries and within their judicial system that was called judgment. This reference formed in subsets of international organizations was created to resolve international disputes that generally was concerned in the international trade disputes between natural or legal persons. This is in a series of international law, in the form of legislation and judicial procedures that in this study we analyzed it.
\end{abstract}

Keywords: arbitration, international commercial arbitration, the arbitral tribunal, the place of arbitration

\section{Introduction}

Almost all legal systems, dispute resolution is accepted by the judges in the state court system. In Article 139 of the Constitution of the Islamic Republic of Iran, with the implicit acceptance of recourse to arbitration for dispute settlement claims relating to public and state property is quite necessary. Limited knowledge of the Majlis and approved by the Cabinet and approved by the Parliament in important cases. Article 454 General and Revolutionary Court in Civil Law Act approved in 2000 and paragraph 2 of Article 2 of the Law on International Commercial Arbitration Approved 1997 decreed: All persons who have the capacity to litigate a case can with mutual consent to each other whatever bring a suit in court or not and if bring a suit in each stage refer to arbitration of one or more persons. In the next article is provided that the parties can in deal and with cause to contract mutual consent separately that if disputes between them refer to arbitration and they can determine their arbiter or arbiters. Arbitration can be known as the most widely used and most closely judicial and formal methods of resolving disputes in domestic and international law, particularly international trade.

In some countries (common law legal system) stepwise courts of justice and official judgment arbitral tribunals set up and provide to resolve disputes. In this country, usually address the claims is in one stage and that there is deep conflict between judicial and arbitration proceedings. In other countries, despite the three-stage maturity judicial system sometimes by law and sometimes by mutual consent of the court usually be entered appointment of the arbitrator or determine after the stipulation, referring to the judgment.

In this article we survey the rules and procedures governing international arbitration and in order to avoid prolongation of sentences, we avoide of rules governing the internal arbitration.

Our international arbitration lawyers represent private corporations and state-owned enterprises in major 
international disputes all over the world. The practice embraces disputes from a broad range of areas: oil and gas, construction, energy and infrastructure projects, concessions, off-take agreements, finance and corporate transactions, joint ventures, insolvency, insurance and reinsurance, fraud, accountants' liability, intellectual property, environment, distribution, import and export, and numerous others.

\section{History of Arbitration in International Law}

In international relations, arbitration has been recognized as a method of peaceful settlement of disputes between States, Article 37 of the 1907 Hague Convention, is about the pacific settlement of international disputes concerning

The parties have the right to appoint delegates or special agents to attend the Tribunal, for the purpose of serving as intermediaries between them and the Tribunal. They are further authorized to retain, for the defense of their rights and interests before the Tribunal, counsel or advocates appointed by them for this purpose.

Arbitration historically has been a long history and for a long time, this method existed for dispute settlement; but we can say that the history of modern international arbitration, since the contract concluded between England and America namely "Ji contract" begins.

Todays base on "non-nationalization of claims' arbitration, a new vision is taking shape, based on which parties to the contract and arbitration tribunals can instead of choosing a national law choose "Rules of law" as the law governing the nature of the dispute (Lynch, 2003, 95-168).

Some countries also have laws adopted by the parties' choice of law rules. Of course, they are usually the choice of such rules have limited the arbitration tribunals.

Despite the ambiguity of the meaning of words, rules of law, You can use it against the law to concluding words that despite the law which is enacted by a government in a particular country (National Law), legal rules have Non-national in nature and is not enacted by government. For example, regulations or Islamic jurisprudence, general legal principles, custom of the trade and regulated rules by international organizations such as the Principles of International Commercial Contracts that was created by the Institute for the unification of Private Law put among legal rules.

The principles and contract are in general, due to legal texts, international legal instruments, contracts, and international litigation. Today, the principles of international commercial contracts (of these principles) are mentioned as a well-known document in the field of international trade law Which in practice is widely used to resolve disputes (www.Cafehoghough.com).

\section{Definition of Arbiter}

With the exception of international commercial arbitration law in Iran we cannot find a definition about the arbitration in international documents Paragraph (a) of Article I of the Law on Iran International Commercial Arbitration says: "arbitration is a dispute resolution between parties to disputes out of court by a person or natural or legal persons mutually acceptable or appointment."

In another place arbitration was known as convention whereby two or more people agree to these disputes concerning its relations to address and resolve refer to one or more persons (Jonidi, 1999: 25).

From the above definitions can be taken two points:

A- source of arbitration is conventional.

B- arbitration is a private judgment; it means that the arbitration has a judicial mission and the obligation is to settle the dispute by issuing a strong decision he called "arbitration Verdict" and arbitration Verdict is the practice that judges would resolve the issue of referral from the parties and arbiter Verdict has credit of matter adjudged by civil jurisdiction.

The Verdict judicial character has an important effect and it is that as soon as the arbitration Verdict is binding on the parties and in this way, can be distinguished arbitration on the other ways of peaceful settlement of disputes, such as conciliation, expertise and in which the decision is not binding on third parties for parties.

To express the concept of arbitration can be said "arbitration is a technique that is aimed at resolving an issue related to relations between two or more persons by one or several persons that called arbiter (Safaee, 1996: 84)

Arbitral Verdicts are separated into two groups of domestic arbitral Verdicts and foreign arbitral Verdicts. The advantage of these two separate categories are ideas about how to identify and enforcement of the arbitration. 


\section{Domestic Arbitration Verdict}

Domestic arbitration in the proper sense is arbitration that all its component elements such as the nature arbitration, nationality parties and judges, law implementation and the place of implementation of Verdict was related to separate political sphere. For example, when the subject of arbitration was the settlement of disputes between the two Iranian citizens to fight in Iran was considered by Iranian arbitration and to comply with Iranian law (Nasiri, 1993: 21).

\section{Foreign Arbitration Verdict}

About the definition of a foreign arbitration Verdict, said: "Verdict is issued in the territory of a foreign country and according to the agreement, the parties were removed and replaced by court and its implementation order issued by a foreign competent judicial authority"(Ibid., 24).

\section{International Arbitration}

Interpretation of international arbitration is usually used in two separate concept one in term of commercial arbitration between private parties or between private entities and government institutions that performed in non-national level and in accordance with the non-national trail procedure such judgments that are subject to arbitration provisions of the International Chamber of Commerce or judgments, subject to the provisions of investment dispute settlement between states and nationals of other states or ad hoc arbitrator which for example performed in accordance with UNCITRAL arbitration rules. The second in its true meaning and to judgments which is taking place between states and is the subject of dispute settlement intergovernmental.

In international arbitrations should this note should be considered that after submission of the dispute to arbitration arbitral tribunal must consider them and issue its final verdict.

The court can resolve many of the disputes referred to as product conformity with contract and paying the purchase money directly through the interpretation and application of the provisions of the contract and without reference to the provisions of a special law. In some cases, a judgment based solely on the terms of the contract may not be possible arbitral tribunal must necessarily refer to a rule or set of rules. Such law or rules of law may by parties of contract were specified explicitly or implicitly and shall determine and apply in the absence of such a choice the arbitral tribunal (Lalive,2002,77-8).

\section{Rules Governing the International Court of Arbitration}

In general, the law has three areas in the broad sense and concept substantive law, conflict rules, regulations and procedures to govern. Our purpose here is of course the first concept.

In understanding the laws of nature, for example, parties (Iran and America) in Article 5 set to resolve claims fairly detailed statement of the law governing the claims filed with the court of arbitration and need specific instructions has to the court since multi-jurisdictional authority of the arbitral tribunal the mentioned different legal sources put into the court to the legal norms and rules required by the mining and related litigation applied it. But with delving into it will be determined that the core and center of gravity Court ruling legal regimes are general international law and refer to legal sources of international law embodied in the material (Eftekhar Jahromi, 1993: 59).

Court procedure also reflects this view as we shall see. That explains the need of expanding speech. The legal regime governing the arbitration tribunal resolved in Article 5 of the statement, is decomposed into three components:

A: According to the law.

B) By applying the rules of law and principles of commercial law and international law.

(C) Taking into account the relevant trade practices, contractual terms and conditions change.

As the name suggests a language that is different for each of the three above once gone: "Based on", "applying" and "taking into account". Each of these phrases carries a certain concept the first two components are related to the primary sources of law have a kind of obligation, while the provisions of part three rather than are the substantive law governing such guarantees that could be the basis for resolving the dispute are speaks of concerns that arbitration tribunal should consider to them. In addition, the content of the first two components are the sources of international law while the third component consists of private rights considerations.

The result is that conform with Article 5 of the statement of the settlement includes the Court obligation to comply with international law as the primary source of law and next to the shed to see and comment secondary sources such as trade practices, contract conditions and changing circumstances. The practical effect of this is the 
result and we will see in the analysis of the sense of Article 5.

Each of the three parts of Article 5 has receiving meaning. But, as we explained attention and look at all three of them is in international law. With "The Legality" or "respect for the law"; this term is not without precedent in international law texts and when it is applied has been overseeing to international law. For example, as previously cited article 37 of the adopted by the Hague Peace Conference Convention of 1907 like Article 15 of the 1899 Hague Convention Provides: "The goal of the international arbitration is dispute settlement between judges chosen by their governments and based on respect for the law" (Eftekhar Jahromi, 1993: 59).

\section{Sources of International Arbitration Law}

Legal Rules of International Arbitration have the resources; in the following we refer to some of the most important of these resources:

1) Geneva Protocol about the arbitration conditions (1923)

2) New York Convention regarding to recognition and enforcement of foreign arbitral awards (New York 1958)

3) European Convention regarding to International Commercial Arbitration (Geneva, 1961)

4) Convention of investment dispute settlement between states and the followers of other states (Washington, 1965)

5) UNCITRAL Arbitration Rules (adopted by the UN General Assembly)

6) UNCITRAL Model Law International Commercial Arbitration (adopted by the UN General Assembly 1985)

A mentioned note regarding these conventions and other relevant international documents it is mainly applied to contractual disputes such as the Geneva Convention 1961 or Washington Convention 1965.

But others are applied regarding any dispute arising from a legal relationship, whether contractual or otherwise, such as the New York Convention of 1958 and the UNCITRAL Model Law in 1985. The other point is cosidering to the convention is a means of dispute settlement so often conventions pay attention to form and ritual issues which is selected them by the parties. However, some of the conventions knows form and function of the law of the place of the arbitration verdict have lost such as the 1958 New York Convention or the referees such as the UNCITRAL Model Law 1985 (Mauro Rubino - Sammartano, 2001,50-48).

However, there are a number of laws that are not part of mentioned rules but the parties are required to comply with their international claims. Including institutional rules of arbitration, the parties agreed rules, regulations within the country (in some circumstances).

\section{The Rules of Arbitration Institutions}

This set of rules prepared by organizations or arbitration centers. These rules are effective and implemented when clearly chosen by the parties or they specifically agree to arbitration under the arbitration institution. Some of these rules are as follows:

A- conciliation and arbitration rules of the International Chamber of Commerce Court that is related to court of Arbitration of the International Chamber of Commerce.

B- International Arbitration Rules of the London Court of International Arbitration Court in London.

C- Arbitration Rules of the European Court of Arbitration

D- Arbitration Rules of Arbitration Association of America (Ibid, 59-56).

\section{Mutual Agreement}

Agreement and will of the parties are the main source of international arbitration law what is agreed in the original contract during or after contingency arrangements to perform their differences (Mauro Rubino Sammartano, 2001, 56).

It must be pointed out that both the Swedish and the English approach find a basis in international instruments on arbitration. The 1958 New York Convention on Recognition and Enforcement of Foreign Arbitral Awards, which successfully creates a uniform law on the enforcement of awards in the about 150 countries that have ratified it (including Sweden and England), says in article V(1)(a) of the Convention that one of the grounds for refusing recognition or enforcement of an award is that one of the parties of the arbitration agreement was under some incapacity under its own law, or that the arbitration agreement was invalid under the law that the parties 
subjected it to, or failing a choice made by the parties, under the law of the place where the award was rendered.

\section{The Rules of the Domestic Legal Systems}

International arbitration proceedings may refer to a national procedural law that, in which case it shall be lawful for international arbitration. Of course, some countries have been provided in its legislation, certain rules for international arbitration and had been distinguished them of domestic arbitration rules. Another point is that arbitral awards are not generally released unless it be attacked or the recognition or enforcement of them to be raised. Of course, the exceptionally International Chamber of Commerce awards, publishes in "Journal of International Law" and vote Claims Tribunal Iran and America. Personal opinions are sometimes offered and publishes into legal journals that this case often do by "Yearbook of International Arbitration". However, as the Court of Arbitration in the case of 1986 (the case is related to ICSID) has stated arbitration procedures basically has no obligation nature. At the same time the old ideas are usually studied carefully by judges and can be a good guide for judges. Even in many cases the former vote and practices were cited by judges and is mentioned in the award. (Especially the International Chamber of Commerce votes and oil claims).

It is also noteworthy that beside the arbitration procedure issued many votes both by the domestic courts of arbitration from different countries which can be a good source of information for those who study international arbitration drawn, although they are not compelling feature.

When parties enter into a contract that has connections with more than one State, the question of which set of legal rules governs the transaction necessarily arises. The answer to this question is obviously important to a court or arbitral tribunal that must resolve a dispute between the parties, but it is also important for the parties themselves, in planning the transaction and performing the contract, to know the set of rules that governs their obligations.

Determination of the law applicable to a contract without taking into account the expressed will of the parties to the contract can lead to unhelpful uncertainty because of differences between the solutions from State to State. For this reason, among others, the concept of "party autonomy" to determine the applicable law has developed and thrived.

Party autonomy, which refers to the power of parties to a contract to choose the law that governs that contract, enhances certainty and predictability within the parties' primary contractual arrangement and recognizes that parties to a contract may be in the best position to determine which set of legal principles is most suitable for their transaction. Many States have reached this conclusion and, as a result, giving effect to party autonomy is the predominant view today. However, this concept is not yet applied everywhere (Poudre \& Besson, 2007, 573).

As stated in the introduction to the principles and its application cases noted that if you choose principles by the parties, the principles should be applied (ICC, 1999, 54-39).

Option Explicit methods of principles by contracting parties

Parties to a contract can choose principles in different ways, for example, they can be expressed that their contracts will be subject only to principles or that their contract will be subject to the principles of a national law also said that between select the principles as the law governing contracts or insert it in the contract, there is little practical difference. This choice occurs usually at the time of the contract and before the conflict and in some cases the parties in arbitration proceedings sewer bills at the beginning or at the beginning of the hearing and often with the judges suggested adopted principles as the law governing the dispute. In cases where the seat of arbitration rules of conflict resolution was prescribed choice of principles by the parties and such a choice has been done by them Judges should, in principle follow from such a choice and your vote will be issued based on principles (Moss, 2005, 11-7).

If the jury would not follow the parties choose and gives judgment based on national law or rules of law other than export principles, such a vote is voidable because in such cases the rules of arbitration are not in accordance consent of the parties and the choice of applicable law by the parties was part of the agreement in relation to the arbitration procedures. A mismatch of arbitration regulations by agreement of the parties is why in most legislations is expressed as one of the annulment of the arbitral award.

It is also possible this jury act considered as as acting contrary to the jus cogens headquarters of the Arbitration Act and cause to the invalidity of the arbitration award. In Article 5 (D) (1) the identification Convention and enforcement of foreign arbitral awards in 1958 (New York Convention) also expresses A mismatch with the agreed arbitration procedures as well as one of the reasons for non-recognition and non-enforcement of an arbitration award (Kronke, 2010,296). 


\section{Select General Principles of Law}

The general legal principles can be seen as a set of principles that is common among all or at least most of the countries, such as the principle of good faith and the principle of necessity contracts, therefore, the general legal principles, rooted in national laws, which in some cases may be reflected in an international treaty.

Choosing the general principles of law as the law governing contracts initially was used in contracts that one of the parties was government also, in cases where the use of terms such as rules of natural justice, principles of Anglo-Saxon law, general principles of fairness, and international law by the parties to the contract have been carrying on the general principles of law.

When the internal regulations of the countries is not appropriate to international trade agreements the authors have proposed new rules tailored to the needs of international trade agreements which can for example be referred to the relevant provisions of hardship and purchase. Therefore, in cases where the arbitral tribunal is seeking to apply general legal principles should examine each of the ingredients principles to find out whether the said Article is a general principle of law or not? (http://hvm.ir/print.asp?id=392).

\section{Choosing the International Commercial Customary}

International business practice can be seen as a set of behaviors that commercial relations formed by the action of activists and widely applied by them. It is therefore necessary had differences among the international business practice and general legal principles, because the general legal principles is an essential rule that have rooted in the national laws of the country, while business practice has its roots in business performance and is a supplemental rules.

Maybe sometimes the parties have stipulated in their contract that their obligations will be subject to international business practice. The explicit therefore, it seems important that the parties to a contract obliged to comply with the customary primarily commercial, and the customary as far as does not in contrary to the rules of the Arbitration Act it is obligated for them.

\section{The Determination of the Substantive Law Governing}

Paragraphs 1 and 2 of Article 27 of the International Commercial Arbitration Act states : arbiter will make a decision.according to the rules of law chosen by the parties about the nature of the dispute. Determine the law or legal system of a given country in any way that is done, it will be considered as a reference to the substantive laws of that country.

In the absence of determining the applicable law by the arbiter parties will be consider based on the legal nature of the dispute that under the conflict rules determine it.

In this context, paragraphs 1 and 2 of Article 28 of the UNCITRAL Arbitration Model Law are also stating

The jury will decide on the dispute in terms of rules of law chosen by the parties as applicable rules about the nature of the dispute, any determination of the law or legal system of a given country will be considered as a direct reference to the substantive laws of the country and not its conflict rules unless the parties agree otherwise.

In the absence of substantive law determination by the parties, the jury will apply the law that is determined pursuant to the conflict rules which is appropriated.

According to the judgment is formed based on the consent and agreement of the parties therefore it is obviously essential to determine the law governing in the first place should be considered agreement of the parties. In the absence of substantive law governing determination by the parties, the arbitrator will determine the law (Mauro Rubino - Sammartano, 2001, 251).

Paragraphs 3, 4 and 5 of Article 13 of the International Chamber of Commerce Arbitration Rules states In confirming or appointing arbitrators, the Court shall consider the prospective arbitrator's nationality, residence and other relationships with the countries of which the parties or the other arbitrators are nationals and the prospective arbitrator's availability and ability to conduct the arbitration in accordance with the Rules. Based on this article do not need to let the substantive law governing the arbitration agreement (Safaee, 1996: 32).

\section{The Substantive Law of the Parties to Dispute}

In International Commercial Arbitration, explicit agreement of the parties in determining the substantive law governing, the main criterion is determining the substantive law governing. This view is accepted by all lawyers and even national legal systems. Under Iranian law governing is not to comment explicitly about the substantive law on the determination.

The idea that the jury meeting place is determining the substantive law governing is popular. But we must keep 
in mind that this rule is not always appropriate. For example, the dispute between "A" and "B" by "C" is judged and solely for the convenience of both sides will be held at the " $\mathrm{D}$ " place. But do you really need the law of " $\mathrm{D}$ " country should be the ruling?

Based on it, the theory is not accepted the European Convention on International Commercial Arbitration in 1961 and parties to dispute has been recognized to determine the substantive law governing to the dispute and even parties of dispute have not obligation to refer the determination of the substantive law governing its national law. In case of disagreement the parties, the arbitrators are free within some conflict rules choose the governing law.

The main private rules of the Code of Arbitration which is the International Chamber of Commerce's Arbitration Rules as well as the 1976 UNCITRAL Arbitration Rules and the UNCITRAL Arbitration Model Law 1985 on about the determination of the substantive law governing have followed of the European Convention. In all this set of rules has been emphasized on the discretion of the parties to arbitration as well as the discretion of the arbiter according to some systems of conflict resolution in substantive law governing. For example, paragraph 3 of Article 13 of the International Chamber of Commerce Arbitration Rules and paragraph 1 of Article 33 of the UNCITRAL Arbitration Rules consider arrangements of two parties for the determining factor governing substantive law.

The arbitral tribunal in Iran - United States of America practice has not been uniform despite several decisions about how to choose the governing substantive law. The court is generally avoided the reference to national legal systems for rules governing. In contrast, frequently it is applied non-national principles derived from contracts the parties, the general principles of law or public international law. The court is generally not provided accurate analysis or explanation about how to choose the governing substantive law.

Paragraph 1 of Article 27 of the International Commercial Arbitration Act, refers to this case decreed and state: The "arbitrator" shall issue his award, according to regulatory laws adopted by the parties for investigation of the merits of the dispute. Determination of the Laws or the legal system of a certain country, set in whatever way, shall be considered as referring to the substantive laws of that country. The rules for resolution of conflicts shall not be governed by the provisions of this Article unless the parties have agreed otherwise. This section literally is derived from paragraph 1 of Article 28 of the Model UNCITRAL Arbitration Rules.

\section{The Substantive Law of Arbiter}

If do not determine the substantive law governing the arbitration by the parties it assigned the task of determining to arbiter in fact, paragraph 2 of Article 27 of the International Commercial Arbitration Act to the adoption of paragraph 2 of Article 28 of the UNCITRAL Arbitration Model Law has decreed: In case no governing law has been determined by the parties, the "arbitrator" shall take cognizance of the merits of dispute on the basis of a law which is compatible with the rules for resolution of conflicts.

The main characteristic of the position of international arbitration, which shall determine the law applicable to the nature of the dispute is surely freedom and diagnosis in determining executable rights. Arbitrator responds to the use of this freedom that the legitimate expectation of the parties (http://anzaliarshad.blogfa.com/post-77.asp).

It must be considered usually that the great merit of the arbitration is leaving the courts of justice. The arbitrator should have more authority to determine the rules governing the arbitration; because of the arbitration authority to determine the rules governing the arbitration were recognized both substantive and procedural rules, for the parties.

\section{Non-Codified International Commercial Arbitration}

Paragraphs 3 and 4 of Article 27 of the International Commercial Arbitration Act state:

Paragraph 3: Should the parties explicitly authorize the arbiter, he may give his award by bringing about a compromise made on the basis of equity in an arbitral manner.

Paragraph 4: The Arbitrator shall decide, in all cases, on the basis of the conditions of the contract, and also take into consideration the commercial practice of the subject concerned.

On the model law UNCITRAL Arbitration and International Commercial Arbitration Act was mentioned to three sources judgment. These resources include: (a) equity (b) mediation friendly (village chief secretary) (c) commercial practices.

Common to all three of the sources are their non-codified. Since the end of the first two in paragraph 3 and paragraph 4 of Article 27 of the International Commercial Arbitration Act listed in the first part we survey the 
Justice and fairness, mediate friendly and in the next section we will discuss and convention business.

Justice and fairness, mediate friendly

Paragraph 3 of Article 27 of the International Commercial Arbitration Act identically derived from paragraph 3 of Article 28 of the UNCITRAL Arbitration Model Law. Instead merely the term ex aequo et bono in the arbitration model law "Justice and fairness" has been replaced in the International Commercial Arbitration Act. However, the correct translation of the term is "fairness and common sense" (Taleghani, 1994: 54).

The term has also been inserted in paragraph 2 of Article 33 of the UNCITRAL Arbitration Rules.

Referring to Justice and fairness will cause that the arbitrator regardless of legal rules and the rights of conscience try to recover the right.

Also in paragraph 3 of Article 27 of the International Commercial Arbitration Act encounter with the term "paternalistic". Equivalent to the term is in paragraph 3 of Article 28 of the UNCITRAL Arbitration Model Law. This term has also been inserted in paragraph 2 of Article 33 of the UNCITRAL Arbitration Rules which has been interpreted to friendly mediate. Professor Lu stated that the mediate provided friendly enable the arbitrator makes a decision based on Justice and fairness (Jonidi, 2006: 140).

\section{Commercial Customs}

According to paragraph 4 of Article 27 of the International Commercial Arbitration Act, which is literally derived from paragraph 4 of Article 28 of the UNCITRAL Arbitration Act: The Arbitrator shall decide, in all cases, on the basis of the conditions of the contract, and also take into consideration the commercial practice of the subject concerned. Commercial custom is one of the sources of International Commercial Law which may be general or related to their particular field of business. In most countries it is known as a source of rights. This customs have been developed rarely but the merchant compliance to it that due to merchants operation over the years (Safaee, 1996: 48-49).

\section{Transnational Business Law}

In the last thirty years we have witnessed a flowering term that mentioned as transnational Business Law. This term was used for the first time in the writings of Professor Goldman. He believed that the roots of transnational trade law are the law of nations in ancient Rome (Mauro Rubino - Sammartano, 2001, 269).

Foushar stated that the rights of transnational trade actually made the international community merchants and it has been formed of customs and trade procedures outside the framework of government regulation can be said international trade due to the failure of national trade regulations and collaborating on a global level and also through international trade associations and institutions have created certain rights Apart from domestic law countries (Safaee, 1996: 43).

\section{The Principle of Independence of the Arbitration Clause}

The arbitration clause is the most common form of arbitration agreement and its position in the original contract creates the idea that above mentioned bets is part of the original contract and cannot be separated from it. In other words, arbitration clause has a joint regime with the original contract and follows of it. The arbitration clause is against the idea of independence theory and implies that the above mentioned bets are a separate contract. That is why the validity and invalidity of the original contract is not related to it and if the invalidity of the original contract, if the arbitration clause is valid arbitrator competence is reserved so he / she can examine the invalidity of the original contract claim. Of course, this rule does not justify why in some cases claiming invalidity is exactly monitor to the arbitration clause again judges have jurisdiction to deal with the claim.

The principle of independence of the arbitration clause has been explicitly in some international instruments; such as Article 23 of the UNCITRAL Arbitration Rules, paragraphs 3 and 9 of Article 6 of the rules of the International Chamber of Commerce arbitration and conciliation, article 23 The arbitral tribunal London Arbitration Rules, paragraph 3 of article 5 of the Geneva Convention of 1961, Article 15 of the Arbitration Rules of the Arbitration Association of America. Also the independence of the arbitration clause and the separation of its validity have been confirmed as prime contractor in arbitral decisions (Jonidi, 2008: 68-72).

\section{Jurisdiction Rule to Competence}

As mentioned earlier the rule of the competence is one of the reasons justifying the independence of the arbitration clause. In short, this rule means that a judge or Arbitrator to address the deficiencies that he / she has the authority to competence and he / she has competence recognition or lack competence and jurisdiction of the arbitrator. 
Territory of the rule is to consider two main objections: The first category is competence objections that are not observer the arbitration agreement. In other words, competence objections that is not monitoring the existence or validity of an arbitration agreement, such competence objections raised by the judges' injury or bugs out and exceed the scope of the provisions contained in the arbitration agreement. International arbitration documents about the actions of the competence rule on this category are unanimous objections.

The second category is the jurisdictional objections that are concerning the validity of the arbitration agreement. In this arbitration documents is not in one side and adopted three different approaches. Some authorities believe that the primary authority of the jurisdictional objections to this category of objections. This category knows the courts as competence that considers this issue (Headquarters Court of Arbitration). The third category; however, the primary jurisdiction of arbitration courts accepted the competence judicial authorities in the identification and implementation of an arbitration award.

According to some jurists of our country, most of the arbitration document jurisdiction over the validity of the arbitration agreement put into its jurisdiction the arbitrator or arbitrators. But final right monitor remains for state courts. In other words, arbitrator if knows own as competent he issued a verdict.

So the law was accepted implementing rules to both categories of above problems (Jonidi, 2008: 72-73).

\section{Disqualification of State Courts}

Different laws of the country may adopt different views regarding the effect of an arbitration agreement on jurisdiction.

In general, we cannot present a general rule which is governed the laws of different countries, but it can be said that the arbitration agreement generally leads to the government's lack of jurisdiction. However, in many areas, state courts may do not announce their incapacity in advance, but only if one of the parties objected, they act to this work (Mauro Rubino - Sammartano, 2001, 252).

This note is reflected in some international judgment Such as the Geneva Protocol, the Convention is reflected Washington and the New York Convention (Jonidi, 2008: 49).

In article 2 of the Convention in New York, is predicted: If the parties resolve their disputes in the course of proceedings, through compromise, the "arbitrator" shall issue a writ on termination of the arbitration. Should one of the parties demand for a compromise and the other party makes no objection, the arbiter shall issue the compromise agreement in the form of arbitration award on the basis of the mutually acceptable conditions (Shams, 2005: 535).

However, it should be noted that the lack of jurisdiction of the court is not absolute and the court depending on the legal system of the country preserves its jurisdiction to intervene in some matters (such as the selection of Arbitrators and...) (Mauro Rubino - Sammartano, 2001, 251).

\section{Conclusion}

Arbitration that is formed based on agreement of the parties is known as the most important non-judicial dispute resolution institutions, especially in international trade disputes. Parties to the dispute would be able to resolve their dispute referred to the judicial authorities or act to agreement with each other for obligate arbiter and regulation of arbitration proceedings, including the law governing the nature of the case, investigation procedures, the effect of sentencing, notification, implementation, etc. Of the requirements for handling and settling claims is that arbitrators appointed by the parties or appointed by others, are trusted by both parties to is formed a fair hearing and to dispose of any alloy. Therefore, in most national laws and international conventions, regulation has been established based on the removal of such concerns until the parties would willingly go to arbitration and have no doubt about the result.

In the distant past those who were elected as an arbitrator that are trusted Parties to the dispute. Mutual trust was sanctioned arbitration award. Now, although the situation has been changed and in some cases, the arbitrator does not know the parties or at least one of them, but the ethical principles of impartiality and independence cause to the arbitrator intimacy of parties to dispute in the past has governance the judge today.

International arbitrator today more affected by ethical issues and academic and international positions companies in arbitration.

What has become about over the rules and regulations governing international commercial arbitration, several important conclusions can be briefly noted: 
(A) In International Commercial Arbitration the will of the parties to the dispute is the basis of work. Therefore, in determining the governing law on nature also put utmost respect the principle of party autonomy. Therefore, if the parties have determined the law governing the nature, the arbitrator must comply of it and basically cannot deviate from it.

(B) Supremacy of the will has been accepted principle, not only as a conflict of governing law, rules for determining, but also it is mandatory as a substantive rule. This means that the contents of the contract, if the underlying regulation which is directly applicable, must be respected. This principle is also reflected in the Convention and texts about the international commercial arbitration and also approved by doctrine and international judicial procedures.

(C) If the law governing the nature is not determined by the parties according to new trends in international arbitrations and a theory that todays has more followers had been authorized to the arbitrator in selecting the appropriate conflict rules it means that the arbitrator can recognize the Conflict rule that is appropriate.

(D) In transnational judgments merchant customs is the applicable as one of the sources of law. These customs, especially when contracts have gaps are used and referred. In fact, commercial customs constitute implied will of parties to the dispute and Fills the contract gaps.

\section{References}

Eftekhar Jahromi, G. (1993). The Iran-United States laim Tribunal and its Practie in international Law, 16-17 Law Review, Tehran.

ICC, Case no. 9479 (00.02.1999), ICC International Court of Arbitration Bulletin, vol. 12, no. 2, 2001, pp. 67-73, Unilex: 'In case the arbitral tribunal does not find in the contract or in the usages of international trade a solution to the problems raised by the parties' claims, it must revert to the law applicable to the contract'.

Jonidi, L. (1998). Enforcement of judgments of foreign trade (2nd ed.). Institute of Legal Studies and Research, Tehran.

Jonidi, L. (2006). In international commercial arbitration law. Tehran, Dadgostar publisher.

Jonidi, L. (2008). Review and evaluate the implementation of the law of international commercial arbitration (1st ed.). Publishing college law and political science at Tehran University.

Kronke, H., Nacimiento, P., \& Otto, D. (Eds.). (2010). Recognition and Enforcement of Foreign Arbitral Awards: A Global Commentary on the New York Convention, Kluwer Law International 2010.

Lalive P. (2002). The Unidroit Principles as Lex Contractus, With or Without an Explicit or Tacit Choice of Law: An Arbitrator's Perspective, ICC International Court of Arbitration Bulletin, Special supplement.

Lynch, K. (2003). The Forces of Economic Globalization: Challenges to the Regime of International Commercial Arbitration, Kluwer Law International.

Mauro Rubino - Sammartano, J. D. (2001). International Arbitration Law and Practice (2nd ed.). Catholic University.

Moss, G. (2005). Can an Arbitral Tribunal Disregard the Choice of Law Made by the Parties? Stockholm International Arbitration Review, 1.

Nasiri, M. (1993). Private international law. Tehran, Agah.

Poudre, J.-F., \& Besson, S. (2007). Comparative Law of International Arbitration, Jean Francois poudret, Doctor in Law, Dr, h, c, mult, Attorney at Law and Honorary Professor of the University of Luassanne, Thomson Sweet a Maxwell.

Safaee, S. (1996). International law and international arbitration (3rd ed.). Tehran, Mizan.

Shams, A. (2005). Civil Procedure (basic course) (5th ed.). Tehran, Drac Publisher.

Taleghani, M. (1994). Latin-Persian Dictionary of Legal Terms. Tehran, Yalda.

\section{Copyrights}

Copyright for this article is retained by the author(s), with first publication rights granted to the journal.

This is an open-access article distributed under the terms and conditions of the Creative Commons Attribution license (http://creativecommons.org/licenses/by/4.0/). 